\title{
Video Interaktif Materi Tangga Nada Sebagai Media Pembelajaran di Era Pandemi Covid-19
}

\author{
Arta Mulya Budi Harsono1, Heni Siswantari² \\ 1,2 Prodi Pendidikan Guru Sekolah Dasar, Universitas Ahmad Dahlan, D.I. Yogyakarta, Indonesia. \\ ${ }^{(*)} \bowtie$ (e-mail) artamulyabudi@gmail.com ${ }^{1}$, heni.siswantari@pgsd.uad.ac.id²
}

\begin{abstract}
Abstrak
Pada era pandemi Covid-19 ini, pemanfaatan teknologi memiliki dampak baik bagi peserta didik sekolah dasar maupun guru. Pembelajaran pada era pandemi mengalami beberapa perubahan yang salah satunya adalah pembelajaran daring atau online. Pemanfaatan teknologi berupa media video interaktif pembelajaran dapat mempermudah peserta didik untuk memahami materi yang diajarkan meskipun tidak melakukan pembelajaran di dalam kelas. Penelitian ini menggunakan metode deskriptif kualitatif dengan subyek peserta didik kelas $V$ sekolah dasar. Teknik pengumpulan data dalam penelitian ini menggunakan teknik angket dan observasi. Tujuan studi ini adalah untuk mengetahui penerapan media video interaktif kedalam pembelajaran SBdP secara online selama pandemi berlangsung. Hasil akhir pada penelitian ini adalah media video interaktif yang dijalankan sesuai dengan prosedur penggunaan dapat diterapkan dengan baik dalam pembelajaran SBdP di era pandemi Covid-19.
\end{abstract}

Kata kunci: era pandemi, pembelajaran online, media video interaktif.

\begin{abstract}
In the era of the Covid-19 pandemic, the use of technology has a good impact on elementary school students and teachers. Learning in the pandemic era has undergone several changes, one of which is online learning. The use of technology in the form of interactive video learning media can make it easier for students to understand the material being taught even though they do not do learning in class. This study used a qualitative descriptive method with the subject of fifth grade elementary school students. Data collection techniques in this study using questionnaires and observation techniques. The purpose of this study was to determine the application of interactive video media into online SBdP learning during the pandemic. The final result of this research is that interactive video media which is carried out in accordance with the usage procedures can be applied well in SBdP learning in the era of the Covid-19 pandemic.
\end{abstract}

Keywords: pandemic era, online learning, interactive video media

(c) (1) (-)

This work is licensed under a Creative Commons Attribution-ShareAlike 4.0 International License.

Copyright (C 2021 Arta Mulya Budi Harsono, Heni Siswantari

Proses Artikel

Diterima 04-04-2021; Revisi 28-05-2021; Terbit Online 24-06-2021 


\section{Pendahuluan}

Menteri Pendidikan dan Kebudayaan (Mendikbud) Nadiem Makarim, mempunyai beberapa perubahan dalam sistem pendidikan di Indonesia khususnya pada era pandemi Covid-19. Perubahan tersebut salah satunya adalah pelaksanaan pembelajaran yang dilaksanan secara online. Perubahan ini diterapkan dengan tujuan untuk meminimaslisir penyebaran Covid-19 di Indonesia. Untuk menyiasati ketidak kondusifan di situasi seperti ini, mrtode daring bisa dijadikan salah satu alternatif dalam pelaksanaan pembelajaran. Kemendikbud mengungkapkan bahwa metode daring dapat mengatasi permasalahan yang terjadi selama pandemi berlangsung (Kemendikbud, 2019). Perubahan ini tentunya sudah menjadi langkah pemerintah untuk tetap meningkatkan kualitas pendidikan walaupun dengan keterbatasan keadaan.

Banyak usaha yang telah diupayakan oleh pemerintah guna meningkatkan kualitas pendidikan di tengah-tengah pandemi yang sejalan dengan kemajuan teknologi. Indeks Pengembangan Manusia (Human Development Index) dari UNESCO, mencatat bahwa Indonesia menempati urutan ke-99 pada tahun 1997, ke-105 pada tahun 1998, ke-109 pada tahun 1999, ke-110 pada tahun 2014, dan ke-113 pada tahun 2015. Sejatinya pemerintah Indonesia telah menyediakan anggaran khusus untuk pendidikan, tetapi belum dapat dimaksimalkan dengan baik. Berdasarkan hasil penelitian yang membahas tentang pembelajaran, menerangkan bahwa kurangnya hasil belajar peserta didik dalam pembelajaran terjadi karena belum maksimalnya penerapan kemajuan zaman di bidang IPTEK, sehingga diperlukan beberapa media untuk menunjang suatu pembelajaran (Andriono, 2015; Rizkiansyah \& Sukardiyono, 2013; Rusdewanti \& Gafur, 2014; Sinaga et al., 2019; Winangsit \& Sinaga, 2020; Yunianti, N., Purnama., Nugroho, 2011).

Pembelajaran adalah sebuah sistem atau proses membelajarkan pembelajar yang sudah direncanakan, dilaksanakan dan dievaluasi secara sistematis agar bermacam tujuan pembelajaran dapat dicapai secara efektif dan efisien oleh pembelajar (Komalasari, 2013, p. 3). Di dalam pembelajaran terjadi proses interaksi antara pengajar dan pembelajar guna mencapai tujuan-tujuan pembelajaran itu sendiri. Pembelajaran pada masa pandemi dan perkembangan zaman seperti ini tidak lepas dari peranan Teknologi Informasi yang mampu mempermudah proses pembelajaran (Nurajizah, 2016; Sinaga et al., 2019). Perkembangan Teknologi dalam dunia pendidikan telah banyak memberi pengaruh terhadap pembelajaran. Seperti yang di dapat oleh peneliti saat melakukan observasi di SD Muhammadiyah Suronatan, Yogyakarta bahwa, banyak beredar bentuk-bentuk media interaktif pembelajaran di setiap kelas yang dapat digunakan atau diterapkan dalam pembelajaran.

Media adalah sarana fisik yang memiliki isi berupa pesan atau informasi atau sebuah sarana untuk menyampaikan pesan (Mustaji, 2013, p. 1), sedangkan dalam proses pembelajaran interaktif, komunikasi terjadi dalam beberapa bentuk, yaitu satu arah dan dua arah serta banyak arah yang berlangsung antara pengajar dan peserta didik (Munir, 2009, p. 88). Salah satu jenis media pembelajaran adalah media video interaktif. Menurut (Arsyad, 2017, p. 38), video interaktif adalah suatu sistem penyampaian materi pengajaran yang di mana materi tersebut dikemas dalam bentuk video dan disajikan dengan pengendalian komputer kepada peserta didik yang tidak hanya mendengar suara maupun melihat video, tetapi juga terdapat pemberian respon yang aktif, dan respon tersebut yang menjadi penentu sekuensi penyajian. Berdasarkan penelitian yang dilakukan oleh (Yunianti, N., Purnama., 
Nugroho, 2011), menjelaskan bahwa peserta didik lebih menyukai penyampaian materi dengan penyajian gambar dan video dari pada penyampaian dengan lisan. Peneliti beranggapan bahwa video interaktif menjadi salah satu media yang cocok untuk digunakan dalam pembelajaran pada masa pandemi khusunya pembelajaran Seni Budaya dan Keterampilan (SBdP) pada kelas V Sekolah Dasar.

Pembelajaran Seni Budaya dan Prakarya (SBdP) merupakan interaksi dari proses pendidikan yang di dalamnya terdapat interaksi antara pendidik dengan peserta didik dan interaksi tersebut memiliki tujuan edukatif tertentu menggunakan seni sebagai media pendidikan (Kusumastuti, 2014, p. 8). Berdasarkan penelitian sebelumnya terkait pembelajaran SBdP di era pandemi menjelaskan bahwa, pembelajaran SBdP dimasa pandemi saat ini memang terasa sangat sulit jika dilaksanakan secara daring (Sandi, 2020). Dari pengakuan salah satu seorang guru menjelaskan bahwa selama pandemi mengalami kesulitan pada pemberian materi kepada peserta didik. Salah satu point penting yang dapat diambil dalam konteks Pendidikan musik pada kondisi seperti ini adalah diharapkan peserta didik mendapatkan pemahaman yang dapat menambah wawasan apresiasi siswa tanpa mengekang kreativitas siswa yang mana akan kembali lagi pada estetika suatu karya musik, salah satunya dilihat dari unsur-unsur pendukung dan pembentuk musik, baik dari kacamata barat maupun tradisional (Sinaga, 2020, p. 990).

Dari pembelajaran SBdP tersebut, materi yang akan dibahas adalah materi tangga nada. Alasan penggunaan materi tangga nada ini berdasar pada hasil observasi pembelajaran dan wawancara kepada guru kelas di SD Muhammadiyah Suronatan, Yogyakarta. Permasalahan yang dihadapi peserta didik adalah ketersedian materi pembelajaran yang sulit dipahami terlebih lagi bila tidak dilakukan pembelajaran secara tatap muka. Berbeda halnya dengan kendala yang dihadapi oleh guru kelas $V$ di SD Muhammadiyah Suronatan, kendala yang dihadapi dalam penyampaian materi tangga nada adalah sulitnya menyampaikan materi akibat kurangnya ketersediaan media bantu yang dimiliki dan keterbatasan penyampaian secara online. Media bantu yang diharapkan adalah media yang interaktif dan benar-benar sesuai penyampaiannya dengan perkembangan kognitif peserta didik kelas $\mathrm{V}$ sekolah dasar dan bisa digunakan baik dalam pembelajaran offline maupun online. Salah satu guru bidang studi di SD Muhammadiyah Suronatan pun menyetujui hal yang sama namun dengan tambahan bahwa, media pembelajaran yang di perlukan merupakan media yang mampu memadukan suara dan gambar dalam satu rangkaian. Alasan lain dari pengambilan pembelajaran music khususnya pada materi tangga nada adalah memberikan banyak manfaat baik dari fisik maupun mental peserta didik (Halimah, 2016). Pendapat tersebut dijelaskan berdasar pada karakter peserta didik di kelas $\vee$ yang lebih menyukai media yang asik atau menarik.

Dari permasalahan di atas, peneliti menyimpulkan bahwa diperlukannya penerapan media video interaktif dalam pembelajaran daring selama pandemi ini berlangsung. Untuk mengetahui respon peserta didik dan guru terhadap media video interaktif dalam pembelajaran daring, peneliti akan menyebarkan media video interaktif kepada peserta didik dan guru kelas $V$ sekolah dasar SD Muhammadiyah Suronatan, Yogyakarta. Penelitian ini bertujuan untuk mengetahui kualitas dan kelayakan media video interaktif pembelajaran SBdP materi tangga nada kelas $\mathrm{V}$ sekolah dasar. Akhirnya, setelah terungkapnya informasi tersebut, dapat diciptakan pembelajaran yang efekltif selama masa pandemi Covid-19 berlangsung. 


\section{Metode}

Penelitian ini menggunakan metode deskriptif kualitatif yang bertujuan untuk mengetahui penerapan media video interaktif ke dalam pembelajaran SBdP materi tangga nada di SD Muhammadiyah Suronatan pada masa pandemi Covid-19. Subjek dari penelitian ini adalah peserta didik kelas V dan guru kelas di SD Muhammadiyah Suronatan, Yogyakarta. Teknik pengumpulan data dalam penelitian ini menggunakan teknik observasi. Observasi dilakukan dengan mengumpulkan data-data terkait penerapam media video interaktif dalam pembelajaran SBdP (Hanik et al., 2018; Hasanah, 2017).

\section{Hasil}

\section{Media Video Interaktif Materi Tangga Nada}

Media video interaktif adalah suatu sistem penyampaian pengajaran dimana materi video rekaman disajikan dengan pengendalian komputer kepada penonton (peserta didik) yang tidak hanya mendengar dan melihat video dan suara, tetapi juga memberikan respon yang aktif, dan respon itu menetukan kecepatan sekuensi penyajian (Arsyad, 2017, p. 38). Video interaktif dirancang secara khusus sebagai media belajar yang efektif. Berisi tuntunan praktis secara tepat sasaran, disajikan lewat presentasi audio visual (gambar dan suara) yang dilengkapi dengan suara penuntun berbahasa Indonesia yang jelas dan mudah dipahami dan dikemas dalam program autorun, sehingga dengan $c d$ interaktif peserta didik dapat belajar secara mandiri setiap saat dan akan sangat menunjang bagi pendalaman materi.

Media video interaktif ini dimanfaatkan secara maksimal oleh peneliti sesuai dengan kriteria media pembelajaran yang baik dan penyesuaian dengan pembelajaran di era pandemi Covid-19. Hal itu bisa dibuktikan dengan isi dari video interaktif berupa pembuka, isi, dan penutup. Video interaktif ini dilengkapi dengan kegiatan evaluasi dan praktek bernyanyi sesuai dengan tema pembelajaran dan kemampuan belajar peserta didik.

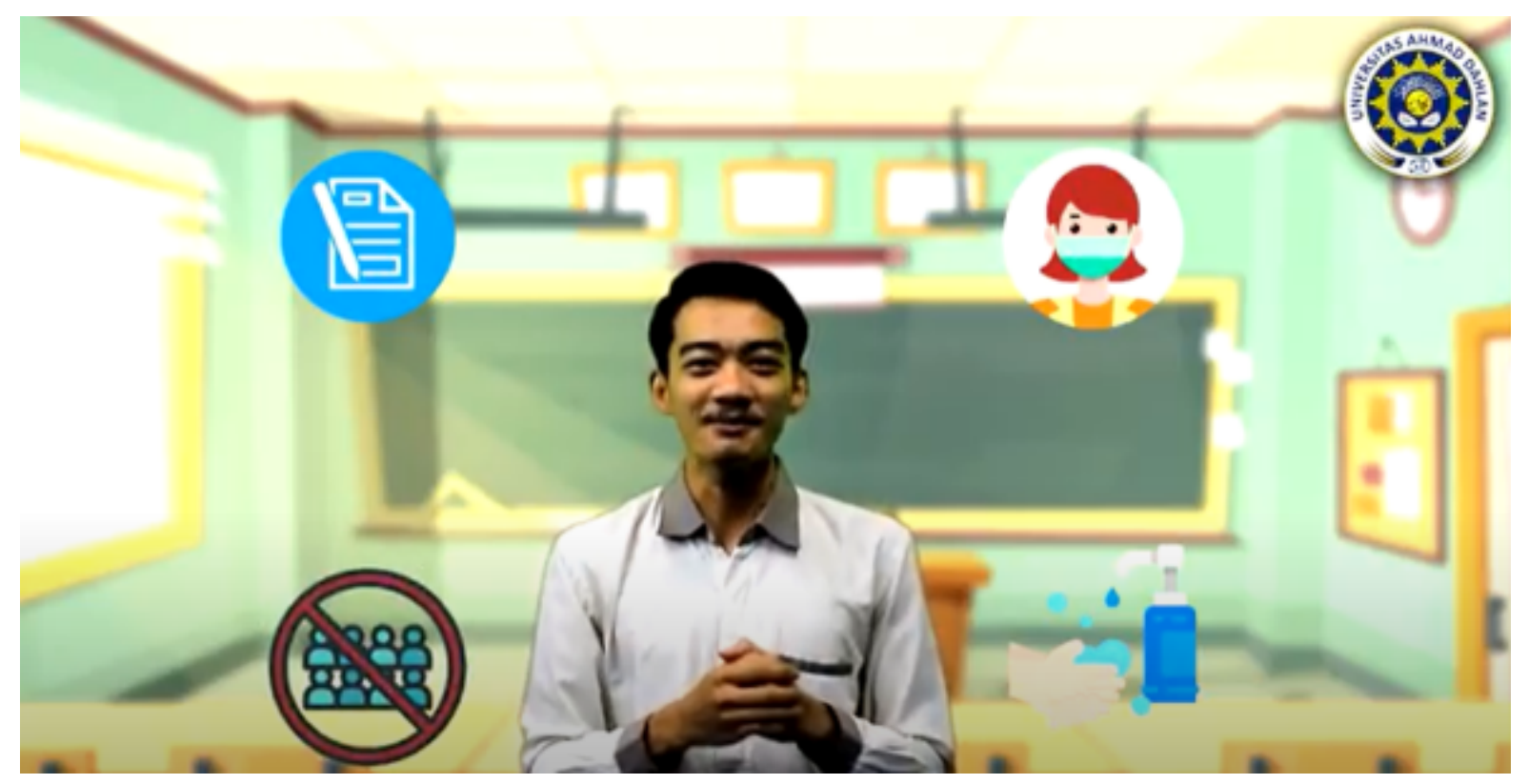

Gambar 1. Scene pembuka video interaktif (Arta, 2021) 


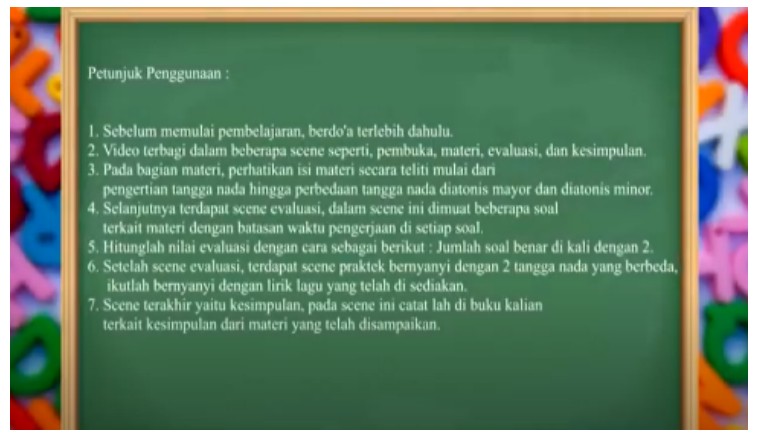

Gambar 2. Petunjuk penggunaan (Arta, 2021)

Scene pertama berisikan salam pembuka untuk memulai pembelajaran dan pemberian himbauan penting terkait dengan pandemi Covid-19 dan petunjuk penggunaan. Himbauan ini bertujuan untuk mengingatkan kembali penonton atau peserta didik untuk selalu mematuhi protokol kesehatan dalam kehidupan sehari-hari di era pandemi. Dengan adanya himbauan ini, diharapkan penonton atau peserta didik secara tidak langsung akan sadar terhadap pentingnya menerapkan protokol kesehatan di era pandemi. Petunjuk penggunakan ditampilkan untuk mempermudah penonton atau peserta didik untuk menggunakan video interaktif. Bahasa yang digunakan dalam petunjuk penggunaan juga telah disesuaikan dengan karakteristik peserta didik sekolah dasar.

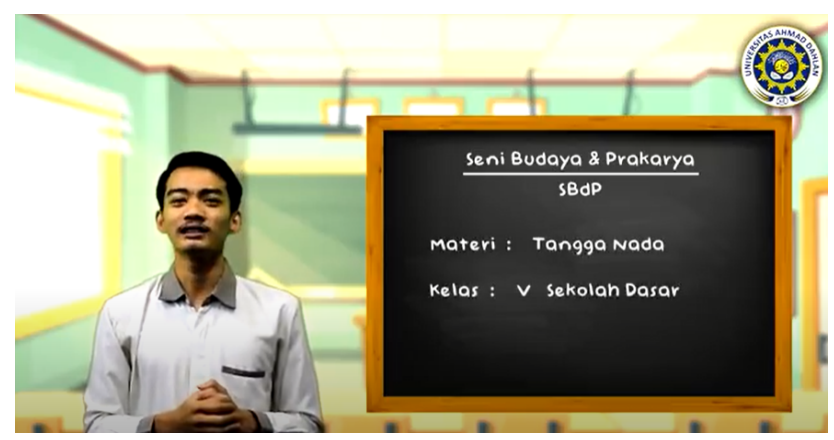

Gambar 3. Scene identitas materi (Arta, 2021)

Scene kedua berisikan tentang penjelasan identitas materi mulai dari pembelajaran, materi, kompetensi inti, kompetensi dasar, dan indikator. Pembelajaran yang dipilih adalah pembelajaran SBdP materi tangga nada. Pemilihan ini didasari pada hasil observasi peneliti terkait materi tangga nada bahwa ketersedian materi pembelajaran yang sulit dipahami. Dalam pembelajaran, peserta didik terus menerus mendapatkan teori dalam waktu yang banyak. Akibat dari banyaknya waktu yang terbuang saat memahami suatu teori menyebabkan kurangnya waktu yang dapat digunakan peserta didik untuk melatih keterampilan yang telah mereka dapatkan. Terlebih lagi terbatas nya waktu yang digunakan dalam pembelajaran daring yang sekarang sedang diterapkan.

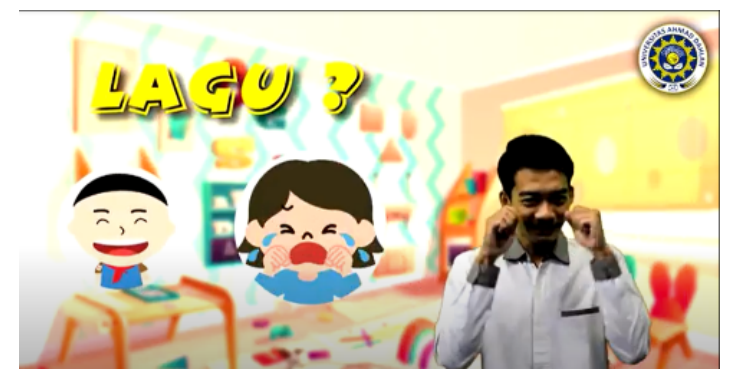

Gambar 4. Scene materi tangga nada (Arta, 2021) 


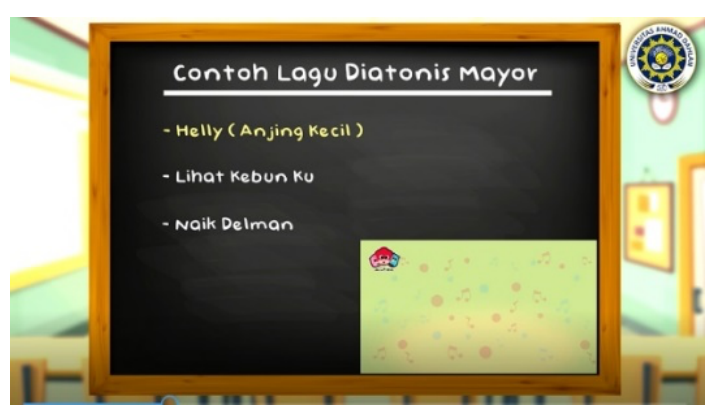

Gambar 5. Scene contoh materi (Arta, 2021)

Scene ketiga berisi penjelasan terkait materi tangga nada yang dilengkapi dengan contoh. Materi yang ditampilkan dalam video interaktif telah disesuaikan dengan kemampuan peserta didik dan pemberian contoh ditampilkan agar peserta didik semakin memahami materi yang disampaikan. Adapun materi yang disajikan berupa pengertian tangga nada, perbedaan tangga nada diatonis mayor dan diatonis minor, contoh lagu berdasarkan tangga nada.

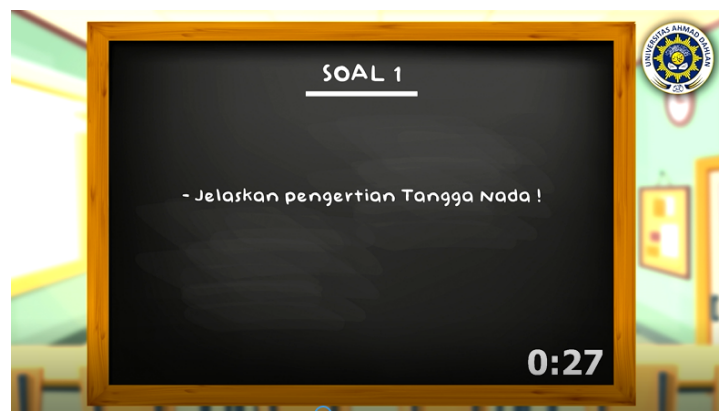

Gambar 6. Scene soal (Arta, 2021)



Gambar 7. Scene pembahasan soal (Arta, 2021)

Scene selanjutnya berisikan 5 soal terkait dengan materi yang disajikan dan dilengkapi dengan pembahasan serta cara penilaian terkait hasil yang dikerjakan oleh peserta didik. Soal yang dipilih telah disesuaikan dengan materi tangga nada kemampuan peserta didik. Pada bagian soal, dalam video interaktif dicantumkan batasan waktu pengerjaan yang disesuaiakan dengan tingkat kesulitan soal mulai dari 30-60 detik. Peserta didik juga diberikan tutorial atau cara penghitungan skor berdasarkan hasil pengerjaan mereka masing-masing dengan tujuan agar peserta didik mampu mengukur tingkat pemahaman mereka secara mandiri.

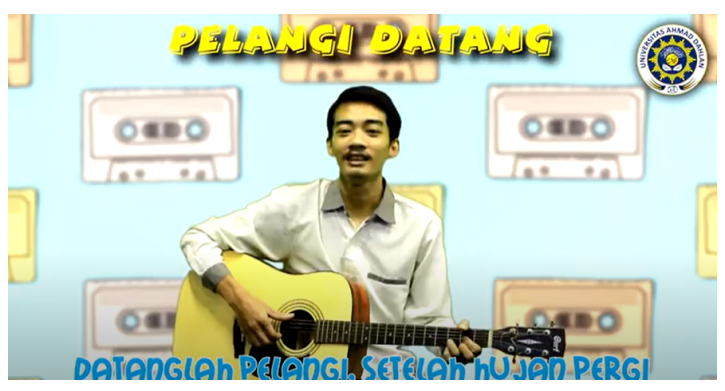

Gambar 8. Scene praktek bernyanyi (Arta, 2021)

Video interaktif ini dilengkapi dengan kegiatan praktek bernyanyi guna meningkatkan kemampuan motorik peserta didik. Lagu yang dipilih adalah lagu anak yang ditampilkan sebanyak 2 lagu. Lagu yang ditampilkan juga berupa lagu anak yang telah ada dan di aransemen oleh peneliti pada segi lirik lagu agar menampilkan kesan kreatif pada peserta 
didik. Setelah diaransemen, terciptalah lagu dengan judul "Pelangi Datang" yang diadaptasi dari lagu kasih ibu dan "Sahabat Ceria" yang diadaptasi dari lagu burung kutilang.

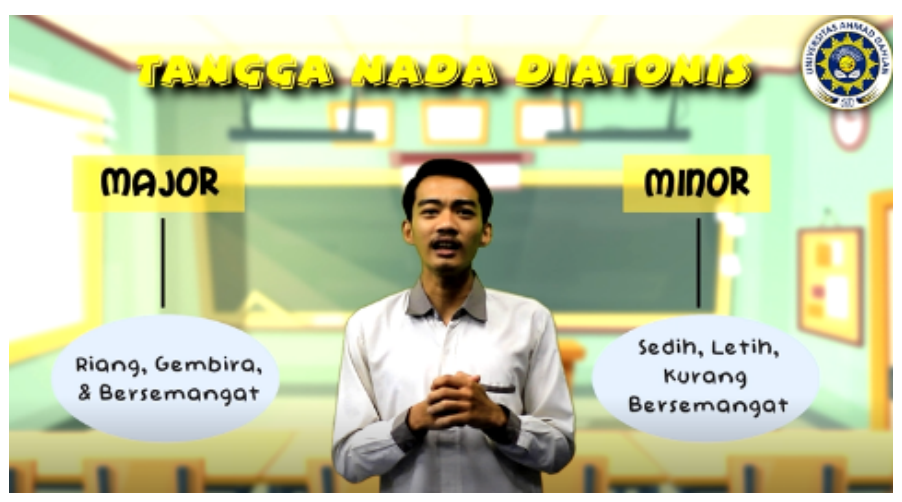

Gambar 9. Scene terakhir video interaktif (Arta, 2021)

Scene terakhir dari video interaktif berisi tentang kesimpulan. Kesimpulan yang disajikan berisi tentang pembahasan secara ringkas dari keseluruhan materi tangga nada. Materi yang disimpulkan dimulai dari pengertian tangga nada, jenis-jenis tangga nada, serta contoh lagu dengan tangga nada yang berbeda.

Video interaktif ini disajikan dengan penggunaan background berwarna yang berbedabeda di beberapa scene-nya. Penyesuaian background ini dilakukan agar video interaktif tidak terkesan monoton atau membosankan. Video ini juga dilengkapi dengan backsound disepanjang video. Backsound yang dipilih adalah instrumen lagu anak dan berbeda-beda pada setiap scene-nya dengan tujuan menghindari penonton atau peserta didik merasa bosan.

\section{Prosedur Penggunaan Media Video Interaktif Materi Tangga Nada}

Video interaktif materi tangga nada dikemas ke dalam bentuk compact disc atau $C D$. Pengemasan ini dipilih dengan berjalannya pembelajaran secara online. Terdapat beberapa cara penggunaan media video interaktif ini disesuaikan dengan pembelajaran yang digunakan. Penggunaan media ini dibagi kedalam 2 jenis, yaitu penggunaan dalam pembelajaran offline dan penggunaan dalam pembelajaran online.

Penggunaan secara offline dilakukan apabila ada kemungkinan pembelajaran dilakukan secara langsung atau tatap muka. Dalam pembelajaran langsung, biasanya guru memberikan sebuah contoh atau media pembelajaran yang dapat digunakan secara bersama oleh peserta didik. Oleh karena itu, penggunaan media video interaktif pada kasus ini memerlukan sebuah laptop, proyektor, dan $L C D$. Jika tidak tersedia laptop, bisa digantikan dengan DVD player. Langkah pertama, cd atau compact dics dimasukkan kedalam slot yang tersedia pada laptop atau DVD player. Selanjutnya pilihlah folder yang berisikan media video interaktif materi tangga nada kemudian klik play atau putar untuk memutarnya jika menggunakan laptop. Jika menggunakan $d v d$ player, pengguna hanya menunggu video pembelajaran diputar secara otomatis. Setelah video diputar, arahkan peserta didik untuk mengamati video secara seksama agar seluruh materi dapat dipahami dengan baik. Pada scene soal, arahkan peserta didik untuk mengeluarkan kertas atau buku tulis mereka untuk menjawab pertanyaan yang diberikan. Video pembelajaran akan berlangsung selama kurang lebih 20-30 menit. Apabila ada peserta didik yang tertinggal atau belum memahami materi yang disampaikan, maka guru dapat memutar kembali video tepat pada bagian yang belum dipahami. 
Pengunaan secara online berlaku untuk guru maupun peserta didik. Penggunaan secara online cocok diterapkan pada pembelajaran di era pandemi karena pembelajaran dilakukan dirumah masing-masing. Berkembangnya teknologi pada saat ini memungkinkan hampir seluruh peserta didik memiliki sebuah handphone atau laptop sebagai alat penunjang video pembelajaran. Langkah pertama penggunaan video ini secara online adalah menyiapkan handphone atau laptop. Setelahnya, guru atau peserta didik mengklik atau mengunjungi sebuah link google drive yang didalamnya berisi video interakti materi tangga nada. Adapun link yang dimaksud adalah sebagai berikut :

https://drive.google.com/file/d/18TAYHFIbbXpvmUxBSy7c VG6knoPsoy/view?usp=sharing

Selanjutnya, guru atau peserta bisa memutar video interaktif materi tangga nada secara praktis di mana saja dan kapan saja. Langkah-langkah penggunaan selanjutnya dapat dilihat dalam video. Seperti yang dibahas sebelumnya bahwa video ini dilengkapi dengan petunjuk penggunaan yang mampu menuntun peserta didik dalam kegiatan pembelajaran menggunakan video interaktif materi tangga nada.

\section{Pembahasan}

\section{Kajian Media Video Interaktif Materi Tangga Nada}

Sejalan dengan pembelajaran di era pandemi Covid-19, pemerintah menerapkan metode pembelajaran daring atau sebuah metode yang berlangsung secara online. Kebijakan ini dilakukan untuk meminimalisir penyeberan Covid di Indonesia. Oleh karena itu, pemakaian media video interaktif tangga nada dalam pembelajaran dapat menjadi alternatif untuk digunakan sebagai alat bantu dalam pembelajaran.

Media video interaktif ini dirancang sesuai dengan karakteristik peserta didik sekolah dasar, penyusunan materi sesuai dengan tema pembelajaran, $\mathrm{KI}, \mathrm{KD}$, indikator dan karakteristik peserta didik. Materi yang dipilih dalam penelitian ini adalah pembelajaran SBdP Kelas V Tema 2, Subtema 2, Pembelajaran 2 dengan materi tangga nada. Materi tangga nada pada penelitian ini memiliki kompetensi dasar dan indikator sebagai berikut:

\section{Kompetensi Dasar}

\subsection{Memahami Tangga Nada}

4.2 Menyanyikan lagu-lagu dalam berbagai tangga nada dengan iringan musiknya

\section{Indikator}

\subsubsection{Mengartikan tangga nada dengan bahasa sendiri}

\subsubsection{Menerangkan tangga nada mayor dan tangga nada minor}

\subsubsection{Membedakan tangga nada mayor dan tangga nada minor}

\subsubsection{Menyanyikan dua lagu dengan tangga nada berbeda}

Adapun pemilihan materi tangga nada di dasari pada hasil observasi peneliti saat proses pembelajaran. Pada materi tangga nada, peserta didik mengalami kesulitan untuk memahami materi karena penggunaan kalimat yang susah untuk dipahami. Oleh karena itu, media ini digunakan dengan menyesuaikan materi terhadap karakteristik peserta didik (Daryanto, 
2013: 9). Media ini sudah dikembangkan seoptimalkan mungkin sehingga dapat mengakomodasi gaya belajar peserta didik (Kurniawan, 2017: 10).

Media video interaktif materi tangga nada mampu memudahkan peserta didik untuk memahami materi dan mampu meningkatkan motivasi belajar peserta didik. Media pembelajaran dapat memperjelas penyajian pesan dan informasi sehingga dapat memperlancar dan meningkatkan proses hasil belajar. Media video interaktif pembelajaran SBdP materi tangga nada sesuai dengan materi yang diajarkan, praktis untuk digunakan oleh guru dan peserta didik, serta media layak digunakan pada pembelajaran Media ini juga menggunakan unsur lagu anak sebagai backsound dan lagu anak digunakan dalam kegiatan praktek bernyanyi. Pemilihan lagu anak ini di dasar karena dampak positif dalam lagu anak yang mengajarkan tentang suatu tindakan sopan santun yang dapat mempengaruhi pikiran, jiwa, dan raga peserta didik. Media video interaktif materi tangga nada ini menggunakan lagu anak yang sudah di aransemen terlebih dahulu agar berbeda dari aslinya dan lebih bervariasi. Oleh karena itu, media video interaktif pembelajaran SBdP materi tangga nada melalui lagu anak untuk kelas $\mathrm{V}$ sekolah dasar layak untuk digunakan dalam pembelajaran.

Penerapan media video interaktif dalam pembelajaran memiliki beberapa keuntungan berupa minimnya kontak fisik yang terjadi, kepraktisan pembelajaran yang dilaksanakan, memudahkan guru dan peserta didik dalam kegiatan belajar mengajar, bisa digunakan secara terus menerus tanpa ada batasan waktu, serta dapat melengkapi ketersediaan media pembelajaran di sekolah. Penggunaan media bisa disesuaikan dengan kebutuhan dan kondisi pembelajaran baik secara online maupun offline. Meskipun demikian, penggunaan media secara online atau offline tidak mengurangi nilai guna dari media karena media bersifat fleksibel dan cocok digunakan sebagai alat bantu dalam pembelajaran.

\section{Kesimpulan}

Berdasarkan hasil dan pembahasan dapat disimpulkan bahwa media video interaktif tangga nada dapat diterapkan dalam pembelajaran di era pandemi. Media video interaktif ini telah disesuaiakan dengan karakteristik peserta didik dan kondisi pembelajaran di era pandemi. Isi video juga dilengkapi dengan himbauan terkait Covid-19 dan materi tangga nada yang disajikan lengkap dengan contoh serta kegiatan praktek bernyanyi menggunakan lagu anak. Media video interaktif dalam pembelajaran di era pandemi memiliki beberapa keunggulan yang bisa dimanfaatkan untuk meningkatkan kualitas pendidikan. Untuk dapat meningkatkan pemanfaatan media video interaktif selama pembelajaran di era pandemi, langkah selanjutnya adalah perlu adanya sosialisasi terkait penerapan media interaktif selama pembelajaran diera pandemi berlangsung. Dengan demikian, penerapan media video interaktif tersebut perlu terintegrasi dalam praktik pembelajaran yang dilakukan selama era pandemi Covid-19.

\section{Referensi}

Andriono, T. N. (2015). Multimedia Interaktif Alat Musik Tradisional Kolintang. CALYPTRA, $3(2), 1-11$.

Arsyad, A. (2017). Media Pembelajaran. Rajawali Pers.

Daryanto. (2013). Media Pengajaran. Gava Media.

Halimah, L. (2016). Musik Dalam Pembelajaran. Jurnal Pendidikan Dasar Kampus Cibiru, 2(2), 9. 
Hanik, N. R., Harsono, S., \& Nugroho, A. A. (2018). Penerapan Pendekatan Contextual Teaching And Learning Dengan Metode Observasi Untuk Meningkatkan Hasil Belajar Pada Matakuliah Ekologi Dasar. Jurnal Pendidikan Matematika Dan IPA, 9(2), 127-138.

Hasanah, H. (2017). Teknik-Teknik Observasi (Sebuah Alternatif Metode Pengumpulan Data Kualitatif IImu-IImu Sosial). At-Taqaddum, 8(1), 21-46.

Kemendikbud. (2019). Merdeka Belajar. Merdeka Belajar.

Komalasari. (2013). Pendekatan Kontekstual. PT. Refika Aditama.

Kurniawan, M. R. (2017). Analisis Karakter Media Pembelajaran Berdasarkan Gaya Belajar Peserta Didik. Jurnal Inovasi Pembelajaran, 3(2443-1591), 16.

Kusumastuti, E. (2014). Penerapan Model Pembelajaran Seni Tari Terpadu Pada Siswa Sekolah Dasar. Mimbar Sekolah Dasar, 1(1), 7-16.

Munir. (2009). Pembelajaran Jarak Jauh: Berbasis Teknologi Informasi Dan Komunikasi. CV. Alfabeta.

Mustaji. (2013). Media Pembelajaran. Unesa University Press.

Nurajizah, S. (2016). Implementasi Multimedia Development Life Cycle Pada Aplikasi Pengenalan Lagu Anak-Anak. Prosisko.

Rizkiansyah, I., \& Sukardiyono, T. (2013). Pengembangan Aplikasi Pembelajaran Interaktif Teknik Bermain Piano Berbasis Multimedia Di Lembaga Kursus Musik "Ethnictro" Yogyakarta. Universitas Negeri Yogyakarta.

Rusdewanti, P. P., \& Gafur, A. (2014). Pengembangan Media Pembelajaran Interaktif Seni Musik Untuk Siswa SMP. Jurnal Inovasi Teknologi Pendidikan, 1(2), 153-164.

Sandi, N. V. (2020). Menggambar Dalam Mengembangkan Kreativitas Dan Bakat Siswa Sekolah Dasar. Biormatika: Jurnal IImiah Fakultas Keguruan Dan IImu Pendidikan, 6(1), 79-87.

Sinaga, F. S. S. (2020). Sustainabilitas Pendidikan Musik Selama Pandemi Covid-19. Prosiding Seminar Nasional Pascasarjana (PROSNAMPAS), 3(1), 980-988.

Sinaga, F. S. S., Maestro, E., Marzam, M., \& Yensharti, Y. (2019). Software Sibelius Sebagai Alternatif Penulisan Notasi Musik Di Era Millenial. Musikolastika: Jurnal Pertunjukan Dan Pendidikan Musik, 1(1), 1-6.

http://Musikolastika.ppj.unp.ac.id/index.php/musikolastika/article/view/11

Winangsit, E., \& Sinaga, F. S. S. (2020). Esensi Pendidikan Musik Berbasis Industri Budaya Di Tengah Pandemi Covid-19. Prosiding Seminar Nasional Pascasarjana (PROSNAMPAS), 3(1), 989-995.

Yunianti, N., Purnama., Nugroho, G. . (2011). Pembuatan Media Pembelajaran Interaktif Ilmu Pengetahuan Alam Pada Sekolah Dasar Negri Konyo 1 Sragen. Journal Speed - Sentra Penelitian Engineering Dan Edukasi, Vol. 3. 